\title{
Do Instructional Practices by Madrasah Teachers Promote Numeracy?
}

\author{
Kusaeri Kusaeri ${ }^{1, *}$ Yusuf H.Yudha ${ }^{2}$ Yuna P. Kadarisman ${ }^{3}$ Ahmad Hidayatullah ${ }^{4}$ \\ ${ }^{1}$ Department of Mathematics Education, UIN Sunan Ampel Surabaya, Surabaya, Indonesia \\ ${ }^{2}$ Department of Psychology, Universitas Pancasila, Jakarta, Indonesia \\ ${ }^{3}$ MAN Insan Cendikia Serpong, Tengerang, Indonesia \\ ${ }^{4}$ Directorate of Curriculum, Infrastructure, Institutions, and Students Affairs Ministry of Religious Affairs, Republic \\ of Indonesia \\ *Corresponding author. Email: kusaeri@uinsby.ac.id
}

\begin{abstract}
This study aims to explore teachers' experiences related to the National Assessment (AKM/AKMI), test/explore teachers' teaching experiences that contribute to students' competence in numeracy literacy, and test/explore teacher teaching experiences related to teaching activities that support/less support AKMI. A cross-sectional survey approach with self-report instruments was applied in this study. The data were obtained from a survey of 6,404 teachers from all over Indonesia. Data were analyzed by descriptive statistics (mean, frequency and percentage) combined with regression analysis. Important findings of this study: (a) most madrasah teachers have never attended training, seminars, courses or read reference s (articles or books) related to national assessments (especially AKMI); b) The experience of teachers participating in training, seminars, courses on leadership assignments has a significant contribution on the results of the student's numeracy literacy test; and (c) The type of teacher's experience on reading articles or books on the National Assessment and giving practice questions, quizzes or homework assignments that require students' critical thinking skills contributes to supporting AKMI. The findings indicate the importance of support from madrasah leaders along with related stakeholders in order to always encourage teachers to participate in socialization (training, workshops or seminars related to AKMI). Socialization related to AKMI content also needs to be carried out more massively by the Ministry of Religion (through digital content or various other creative ways in the midst of this pandemic).
\end{abstract}

Keywords: Madrasah, AKMI, Instructional practices, Numeracy.

\section{INTRODUCTION}

Indonesian Madrasah Competency Assessment (AKMI) is an assessment organized by the Ministry of Religious Affairs (MORA) of Republic of Indonesia specifically designed for madrasah students in Indonesia to diagnose the madrasah students' abilities (MORA, 2021). The results of the assessment are used by teachers and madrasahs as the basis for improving the quality of learning, in line with the opinion of [1]. AKMI in particular measures four literacy skills of students from grades 5, 8 and 11 in the fields of reading, numeracy, science and socio-culture by adopting the National Assessment system by the Ministry of Education and Culture (MOEC), Republic of Indonesia by integrating the characteristics of madrasahs.

The characteristics of the madrasahs are manifested in some aspects, namely specific religious subjects being taught at the school, such as: Al-Quran hadith, moral aqidah, fiqh, Islamic cultural history, and Arabic [2] and the atmosphere religious life at madrasah so that the Islamic values in the presentation of lesson materials for each subject. In practice, the characteristics are influenced by many factors including the affiliation of the religious organization or the foundation of the organization [3], [4]. With its uniqueness, it has implications to the learning process, interaction patterns of the students and students with the teachers, all of which also have an impact on how the assessments should be carried out [5], [6]. This fact is used as the basis for developing AKMI in the Ministry of Religious Affairs.

AKMI as a national assessment is believed to be an effective instrument to direct changes and reforms [7]. This kind of assessment tends to be perceived as having 
higher credibility and social value than class assessment [8]. Therefore, this kind of assessment is expected to encourage students to attend classes more often, motivate the students learning behavior and encourage teachers to improve their learning process [9]. In addition, it can also be a model for teachers in terms of how to evaluate student competencies.

In terms of numeracy literacy being one of the literacy skills tested in AKMI, it has different orientations from general Mathematics. In numeracy literacy, the emphasis is more directed at exploring students' abilities in understanding and analyzing reading by using reasoning through the application of calculations involving numbers and mathematical symbols. This ability is then used as the basis for interpreting, predicting and/or making decisions (MORA, 2021). Meanwhile, Mathematics has tended to be studied by students and taught by teachers as a collection of facts, procedures, and formulas that should be memorized and practiced [10], [11]. The shift from Mathematics to numeracy, of course, has caused a shock for both the students and the teachers.

Such assessment provides information regarding the professional identity of a teacher because the statements that arise during the assessment process reflect the identity of a teacher [12]. The professional identity of a teacher will appear when they teach in the classroom [13]. If a teacher in teaching emphasizes more on the application of formulas, not on understanding concepts, then the statements in the assessment submitted to students tend to encourage recall of facts, application of formulas and only formulas [14]. On the other hand, if teachers direct the process of exploration and problemsolving in the teaching practice, they are more inclined to invite exploration and construct understanding when giving mathematical problems [15].

Previous studies and the theoretical bases indicate the need to further explore the readiness of teachers (in terms of teaching experience and teaching style or method) in dealing with the new assessment pattern, i.e. numeracy literacy more comprehensively. Therefore, this study focuses on two main issues, namely exploring teacher's experiences related to national assessment (AKM/AKMI), testing/exploring teacher's teaching experiences that contribute to students' competence on numeracy literacy, and testing/exploring teaching experience of the teachers associated with teaching activities that support/less support AKMI. Empirical evidence from these three things is believed to have an important significant impact for the Ministry of Religious Affairs in preparing and developing the competence of Madrasah Ibtidaiyah (elementary level) teachers in responding to the change in assessment from the National Examination UN) to AKMI.

\section{METHODS}

A cross-sectional survey using a self-report instrument was conducted to answer the research questions by distributing online questionnaires via Google Form to all madrasah teachers who are involved in the AKMI pilot program. The point of the questionnaires was to ask the teachers to report on their teaching experience activities and their teaching style. The approach is considered the most appropriate for the purpose of this study, namely exploring the teaching experience and the teachers' teaching methods or styles.

\subsection{Participants}

This study involved 6,404 teachers (4,026 female teachers or $62.87 \%$ and the rest were male teachers) from 34 provinces in Indonesia. The distribution of each island can be classified as 2,010 teachers from Java (47\%), Sumatra 1441 (22.50\%), Kalimantan 467 (7.29\%), Sulawesi 669 (10.45\%), Nusa Tenggara 147 (2.30\%), Maluku 9 (0.14\%), and Papua 217 (3.39\%). In terms of the level education they teach, MI (elementary) level is 3,035 teachers $(47.39 \%)$, MTs (junior secondary) is 1,954 teachers $(30.51 \%)$ and MA (senior secondary) is 1,415 teachers $(22.10 \%)$.

\subsection{Instruments}

The instrument employed for observe the experience of the teachers related to the national assessment (AKMI and $\mathrm{AKM}$ ) consists of four questions which essentially ask the teachers to describe all activities related to the national assessment. The experience gained is obtained from various activities such as training, seminars, courses or reading articles/books on the national assessments.

To observe the opinion of the learning objectives, participants were asked to answer various activities that may support the spirit of the national assessment and activities that are not in accordance with the spirit of the national assessment. Supportive activities such as integrating various information to make decisions, while examples of activities that do not support the spirit of mastering strategies to answer questions effectively. The scale used to measure this aspect ranges from 0 ("don't know") to 4 ("essential or mandatory").

\subsection{Analysis}

The data were analyzed through descriptive statistical analysis (mean, frequency, and percentage) combined with regression analysis which was applied to answer the formulation of this research problems. Regression analysis was carried out by using SPSS v. 23. 
Table 1. Teacher's experience on National Assessment (AKMI/AKM)

\begin{tabular}{|c|c|c|c|c|}
\hline No & Experience while becoming teachers & Answers & $f$ & $\%$ \\
\hline \multirow[b]{2}{*}{1.} & \multirow{2}{*}{$\begin{array}{l}\text { Participating in training/seminars/courses related to the National Assessment as } \\
\text { part of the teacher competency development program on the appointment from } \\
\text { the madrasah leadership }\end{array}$} & No & 5333 & 83.28 \\
\hline & & Yes & 1071 & 16.72 \\
\hline \multirow[b]{2}{*}{2.} & \multirow{2}{*}{$\begin{array}{l}\text { Participating in activities, e.g. training/seminars/courses related to the National } \\
\text { Assessment on their own initiative or not based on the appointment from the } \\
\text { madrasah leadership }\end{array}$} & No & 5908 & 92.25 \\
\hline & & Yes & 496 & 7.75 \\
\hline \multirow{2}{*}{3.} & \multirow{2}{*}{ Reading reference or articles on National Assessment (AKMI/AKM) } & No & 5283 & 82.50 \\
\hline & & Yes & 1121 & 17.50 \\
\hline \multirow{5}{*}{4.} & \multirow{5}{*}{$\begin{array}{l}\text { Employing test, quizzes, assignment or homework that require students to think } \\
\text { critically }\end{array}$} & Absolutely yes & 3901 & 60.92 \\
\hline & & Sort of yes, but unsure & 1733 & 27.06 \\
\hline & & Maybe yes & 483 & 7.54 \\
\hline & & Maybe no & 231 & 3.61 \\
\hline & & Absolutely no & 56 & 0.87 \\
\hline
\end{tabular}

\section{RESULTS AND DISCUSSIONS}

In general, $86.01 \%$ of madrasah teachers have not attended training, seminars, courses and read references articles/books related to the national assessment (see Table 1). This number shows that the Ministry of Religious Affairs (MORA) needs to intensely encourage relevant stakeholders to socialize the policies in relation with the implementation of the national assessment (AKMI/AKM). During the pandemic, the socialization of the policies should be done through virtual meetings. Various digital contents that can provide explanations about AKMI/AKM also need to be massively promoted, either through websites or YouTube channels published and managed by MORA, either regional offices and the central offices through Indonesia. This method should be carried out in order to suppress the limited sources of teachers' reading related to AKMI/AKM.

This conditions are different with teachers of public schools. Research by [16] shows that public school teachers are likely more prepared for the national assessment (AKM). They have long been required to attend workshops or seminars related to AKM with the support from the schools. In addition to workshops or seminars provided by the schools, the teachers are also supported by the online sources through links given by the schools containing socialization of the national assessment as an online reading guide. This is in line with the opinion of [17], that national assessment as something new for the teachers requires support from various parties, such as the education departments and related education units.

Regarding the four types of teachers' experiences presented in Table 1, their contribution to the students' results of the AKMI will be traced (especially numeracy literacy). The results of the regression analysis (Table 2) show that the participation of teachers in training, seminars, courses on assignments from the madrasah leaders turned out to have a significant contribution to students' numeracy literacy skills $(\mathrm{R}=0.217 ; \mathrm{p}=0.036)$.

Table 2. Regression Analysis on the Correlation between Experience on Assessment, Teaching Habits, and AKMI Test Results (Numeracy)

\begin{tabular}{|c|l|c|c|}
\hline \multirow{2}{*}{ No } & \multicolumn{1}{|c|}{ Aspects related to teacher's experience (predictor variable) } & \multicolumn{2}{|c|}{$\begin{array}{c}\text { Results of AKMI tests } \\
(\theta)\end{array}$} \\
\cline { 3 - 4 } 1. & $\begin{array}{l}\text { Participating training, seminar, courses related with national assessment as part of professional } \\
\text { development of the teachers on the appointment of the madrasah principals }\end{array}$ & 0.217 & 0.036 \\
\hline 2. & $\begin{array}{l}\text { Participating training, seminar, courses related with national assessment as part of professional } \\
\text { development of the teachers on self-initiation, not based on the appointment of the madrasah } \\
\text { principals }\end{array}$ & 0.042 & 0.779 \\
\hline 3. & Having read references, articles, or books related with national assessment (AKM/AKMI) & 0.019 & 0.844 \\
\hline 4. & Employing test, quizzes, assignment or homework that require students to think critically & 0.030 & 0.485 \\
\hline
\end{tabular}


Table 3. The results of regression on the relationships between experience on assessment, teaching habits and teaching preference

\begin{tabular}{|c|c|c|c|c|c|}
\hline \multirow{2}{*}{ No } & \multirow{2}{*}{ Aspects related with teachers' experience (predictor variables) } & \multicolumn{2}{|c|}{ Results of AKMI tests $(\theta)$} & \multicolumn{2}{|c|}{ Results of AKMI tests $(\theta)$} \\
\hline & & B & Sig & B & Sig \\
\hline 1. & $\begin{array}{l}\text { Participating training, seminar, courses related with national assessment } \\
\text { as part of professional development of the teachers on the appointment } \\
\text { of the madrasah principals }\end{array}$ & -0.028 & 0.460 & -0.026 & 0.496 \\
\hline 2. & $\begin{array}{l}\text { Participating training, seminar, courses related with national assessment } \\
\text { as part of professional development of the teachers on self-initiation, not } \\
\text { based on the appointment of the madrasah principals }\end{array}$ & -0.020 & 0.698 & -0.046 & 0.385 \\
\hline 3. & $\begin{array}{l}\text { Having read references, articles, or books related with national } \\
\text { assessment (AKM/AKMI) }\end{array}$ & 0.228 & 0.000 & 0.195 & 0.117 \\
\hline 4. & $\begin{array}{l}\text { Employing test, quizzes, assignment or homework that require students } \\
\text { to think critically }\end{array}$ & 0.088 & 0.000 & 0.095 & 0.245 \\
\hline
\end{tabular}

Meanwhile, the other three types of experiences did not contribute to students' numeracy literacy skills. The finding is in line with the research of [18], [19], [1] that a strong leadership which supports the teachers through various trainings to improve their competence for professional development is essential. If the principals and leaders at madrasahs facilitate the teachers to participate in various activities and provide opportunities to participate in self-capacity training programs for professional development such as training, seminars, workshops or courses related to the educational evaluation and assessment, the teachers will be able to apply the experience and updated skills in the context of the classroom. Likewise, if madrasah leaders are able to motivate their teachers to always be involved in the continuing professional development activities above, the implications are positive for the teachers; therefore, the impact to the students being taught will increase as well.

Furthermore, Table 3 presents the results of the exploration of four types of teacher's experiences associated with activities that are believed to support or not to support AKMI. The results of the regression analysis showed that activities or programs in teaching of having read any references, articles, or books related with national assessment (AKM/AKMI) support AKMI $(\mathrm{R}=0.228 ; \mathrm{p}=0.000)$. Another activity from the teacher's point of view that has a positive contribution to AKMI is their teaching strategy on employing test, quizzes, assignment or homework that require students to think critically $(\mathrm{R}=0.030 ; \mathrm{p}=0.000)$. Meanwhile, the other two types of experiences of the teachers did not contribute positively to AKMI and have less contribution to AKMI. In other words, these two types of attending professional development programs like seminar and workshops are still considered confusing for the teachers.

The activities or teaching habits that become teachers' preferences in the context of this study are explained as follows that activities that support AKMI include 1) thinking independently to understand and deal with problems, 2) being able to explain various socialsocial phenomena, 3) reading a text/writing and understanding the authors' implicit intent, combining various information to make decisions, and 4) the ability to convey arguments clearly and logically. On the other hand, activities that do not support AKMI are such as 1) knowing and mastering many facts and information, 2) understanding/mastering various content/topics in the curriculum, 3) mastering strategies for answering questions effectively, and 4) the ability to manage the learning process on their own. The undecided stance from the teachers regarding the two types of activities/experiences is still unclear, and when analyzed the causes are likely: (a) the vignette form of the questionnaire question model as in this study is not familiar for many teachers. So, it is very possible that they had confusion, and (b) the teachers were thought to be less serious when filling out this section because it was located at the very end of the entire questionnaire.

\section{CONCLUSION}

Some important points of this research are that most of the madrasah teachers have not attended professional development activities such as training, seminars, courses or reading references like articles or books related to national assessments (especially AKMI). The experience of the teachers in participating in training, seminars, courses assigned by the madrasah principals is believed to has a significant contribution to the results of students' numeracy literacy tests. Meanwhile, the type of teachers' experience on employing test or assignment that require students' critical thinking and reading references on national assessment contributes to support AKMI. The findings indicate that the supports from the leaders of madrasah are important. In addition, the role of the Ministry of Religious Affairs - both regional offices or central government - need to encourage teachers to 
participate in socialization namely training, workshops or seminars related to AKMI. This is because the results of the regression analysis of this type of experience have an important contribution in improving students' numeracy literacy skills.

\section{REFERENCES}

[1] W. B. Kippers, C. H. D. Wolterinck, K. Schildkamp, C. L. Poortman, A. J. Visscher, Teachers' views on the use of assessment for learning and data-based decision making in classroom practice. Teaching and Teacher Education, 2018, 75, 199- 213. https://doi.org/10.1016/j.tate.2018.06.015.

[2] R. Lukens-Bull, Madrasa by any other name: Pondok, pesantren, and islamic schools in Indonesia and larger southeast Asian Region. Journal of Indonesian Islam, 2010, 4, 1. https://doi.org/10.15642/JIIS.2010.4.1.1-21.

[3] A. Nurokhman, Alternatif Pengembangan Madrasah Berbasis Pesantren. Jurnal Kependidikan, 2017, $5(2)$, 130-139. https://doi.org/https://doi.org/10.24090/jk.v5i2.194 $\underline{0 .}$

[4] T. Muttaqin, R. Wittek, L. Heyse, M. V. Duijn, The achievement gap in Indonesia? Organizational and ideological differences between private Islamic schools, School Effectiveness and School Improvement, 2019, DOI: 10.1080/09243453.2019.1644352.

[5] R. Kingham, J. Parsons, Integrating Islamic schools into the Indonesian national education system: A case of architecture over implementation. In D. Suryadarma \& G. W. Jones (Eds.), Education in Indonesia, 2013, (pp. 68-81). Singapore: ISEAS.

[6] R. Maulana, M. H. Lorenz, W. V. Grift, Development and evaluation of a questionnaire measuring pre-service teachers' teaching behaviour: A Rasch modelling approach. School Effectiveness and School Improvement, 2015, 26(2), 169-194. doi:10.1080/09243453.2014.939198.

[7] A. Looney, Assessment and the Reform of Education Systems From Good News to Policy Technology. In C. Wyatt-Smith, V. Klenowski, \& P. Colbert (Eds.), Designing Assessment for Quality Learning: The Enabling Power of Assessment, 2014, (pp. 233-248), Dordrecht: Springer Science Business Media.

[8] X. Zhao, M. V. D. H. Panhuizen, M. Veldhuis, Teachers' use of classroom assessment techniques in primary mathematics education: an explorative study with six Chinese teachers. International Journal of STEM Education, 2016, 3(19), 2 - 18.
[9] K. Gregory, M. Clarke, High-Stakes Assessment in England and Singapore. Theory Into Practice, 2010, 42(1), 66-74.

[10] K. Kusaeri, A. Aditomo, Pedagogical beliefs about critical thinking among Indonesian mathematics pre-service teachers. International Journal of Instruction, 2019, 12(1), 573-590.

[11] A. H. Dewantara, Zulkardi, Darmawijoyo, Assessing seventh graders' mathematical literacy in solving PISA-Like tasks. Journal on Mathematics Education, 2015, 6(2), 117-128.

[12] N. B. M. Zamri, M. I. B. Hamzah, Teachers' Competency in Implementation of Classroom Assessment in Learning. Creative Education, 2019, 10 , 2939-2946. https://doi.org/10.4236/ce.2019.1012218.

[13] F. Korthagen, A. Vasalos, Levels in reflection: Core reflection as a means to enhance professional growth. Teachers and Teaching, 2005, 11(1), 47-71.

[14] K. Beswick, The beliefs/practice connection in broadly defined contexts. Mathematics Education Research Journal, 2005, 17(22), 39-68.

[15] H. Y. Hong, C. S. Chai, Principle-based design: Development of adaptive mathematics teaching practices and beliefs in a knowledge building environment. Computers \& Education, 2017, 115, 38-55.

[16] Nurhikmah, I. Hidayah, S. Kadarwati, Persepsi dan Kesiapan Guru dalam Menghadapi Asesmen Kompetensi Minimum. CJPE: Cokroaminoto Juornal of Primary Education, 2021, 4(1), 78 - 83.

[17] D. A. Rokhim, B. N. Rahayu, L. N. Alfiah, R. Peni, B. M. Wahyud, A. Wahyudi, Sutomo, H. R. Widarti, Analisis kesiapan peserta didik dan guru pada asesmen nasional (asesmen kompetensi minimum, survey karakter, dan survey lingkungan belajar). JAMP: Jurnal Adminitrasi dan Manajemen Pendidikan, 2021, 4(1), 61 - 71.

[18] M. C. Heitink, F. M. V. Kleij, B. P. Veldkamp, K. Schildkamp, W. B. Kippers,. A systematic review of prerequisites for implementing assessment for learning in classroom practice. Educational Research Review, 2016, 17, 50e62. https:// doi.org/10.1016/j.edurev.2015.12.002.

[19] I. Hoogland, K. Schildkamp, F. V. Kleij, M. Heitink, W. Kippers, B. Veldkamp, A. Dijkstra, Prerequisites for data-based decision making in the classroom: Research evidence and practical illustrations. Teaching and Teacher Education, 2016, 60, $377 \mathrm{e} 386$. https://doi.org/10.1016/j.tate.2016.07.012. 